\title{
Effect of birth difficulty on ewe maternal behaviour and lamb survival
}

\author{
R. A. Darwish \\ Department of Animal Husbandry, Faculty of Veterinary Medicine, Mansoura University, Mansoura, Egypt
}

\begin{abstract}
Survival of the neonate relies on the integrated expression of appropriate behaviours from both mother and young. In this study, the effect of birth difficulty on maternal and lamb behaviours and its influence on lamb survival was investigated in crossbred primiparous ewes ( $1 / 2$ Finnish $\times 1 / 2$ Rahmani). Assisted ewes spent significantly $(\mathrm{P}<0.05)$ less time licking $(30.83 \pm 1.39 \mathrm{~min} / 2 \mathrm{~h})$ and nosing $(24.25 \pm 1.79 \mathrm{time} / 2 \mathrm{hr}) \mathrm{their}$ lambs than unassisted mothers $(38.52 \pm 2.96 \mathrm{~min}, 28.80 \pm 1.68 \mathrm{time} / 2 \mathrm{~h}) \mathrm{respectively}$. They were found to be more aggressive towards their lambs when attempt to suck $(9.80 \pm 0.37$, $12.90 \pm 0.84$ and $10.50 \pm 0.50$ time/2 h) when compared with unassisted one $(8.00 \pm 0.40$, $10.20 \pm 1.52$ and $7.66 \pm 0.88$ time/2h) respectively. Lamb behavioural development were found to be significantly $(\mathrm{P}<\mathbf{0 . 0 5})$ affected by birth difficulty with lambs that require assistance at birth even if they survive the birth process, they were slower to progress through the sequence of neonatal behaviours. These lambs were therefore at greater risk of not surviving to weaning $(28.57 \%$ vs. 11.42). It could be concluded that ease of delivery was an important factor determining the subsequent behaviour of the lamb and ewe and hence lamb survival, thus manipulation of husbandry and breeding system to improve delivery will improve lamb survival.
\end{abstract}

High pre weaning lamb mortality greatly reduces the efficiency and profitability of lamb production. In many flocks all over the world, $10-35 \%$ of lambs die by the six months of age (Rook et al., 1990) with neonatal lambs at greatest risk (Gama et al., 1991). Although most producers realize that an efficient and profitable system should minimize lamb morbidity and mortality, existing programmes may not adequately quantify the factors implicated in lamb deaths (Nash et al., 1996). Two main factors, dystocia and starvation-exposure have been most often implicated with lamb losses, (Dwyer, 2003).

Dystocia was related primarily to presentation problems (Thomas, 1990 and Clarke et al., 1997) but not to ewe age (Knight et al., 1988; Haughey, 1993 and Morris et al., 2000) or pre-lambing ewe body weight but, it would appear that weaker ewes are more likely to have difficult birth than ewes in better condition (Clarke et al., 1997). Additionally, ewe maternal behaviour was known to be affected by difficult delivery (Alexander et al., 1990 and Dwyer et al., 2001). Unassisted ewes gave more appropriate behaviours at birth and tended to remain closer to their youngs during the first hours following birth. On the other hand, assisted mothers appear exhausted with poor mothering ability (Nowak, 1996 and Dwyer et al., 2001) which may influences lamb survival (Nowak et al., 2000 and Darwish, 2004).

It has been known that difficult birth is also associated with slower neonatal lamb behavioural progress, being less active in the early postnatal period (Hinch et al., 1986; Cloete, 1993 and Dwyer, 2003) than lambs with uncomplicated deliveries or those requiring minimal assistance resulting in more lambs deaths (Knight et al., 1988; Fogarty et al., 2000; Nowak et al., 2000 and Darwish, 2004).

The present study investigated how lamb and maternal behaviours were affected by birth difficulty and their consequences on lamb survival.

\section{Material and Methods}

This study was carried out in Sakha Animal Production Research Station, Kafr El-Shiekh Governorate, Egypt during winter season of lambing (February-March, 2005) to investigate the effect of birth difficulty on:

Ewe maternal behaviour, neonatal lamb, behavioural development, and lamb performance and lamb mortality.

Animals. The study was conducted on 42 crossbred single bearing primiparous pregnant ewes ( $1 / 2$ Finnish $x 1 / 2$ Rahmani) with an average body weight of $42 \mathrm{~kg}$ and 15 month of age. Ewes 
were divided into 2 groups according to the need of assistance at delivery 1- unassisted group $(n=35), 2$ - Assisted group $(n=7)$.

Management. Each ewe during the late stage of pregnancy (last 6 weeks) was allowed a diet consists of one $\mathrm{kg}$ concentrate $(16 \%$ protein, according to NRC, 1996) and green fodder (Trifolium alexandrium) that added ad-libitum. Fresh clean water was available at ad-libitum.

Ewes were lambed in large straw-bedded pens $(7 \times 10 \mathrm{~m})$ in groups of 10-12 animals /pen. They were transported to lambing pens 2 weeks before lambing. Ewes were vaccinated with a colostridial vaccine (Covexin) in $17^{\text {th }}$ week of pregnancy.

As far as possible ewes were allowed to give birth and care for their lambs without assistance. However, lambing assistance was given if the ewe had failed to progress through a time schedule of events; one hour after the appearance of fluids without appearance of parts of the lamb and/or 2 hours after parts of the lamb were seen at the vulva without obvious progress being made. In all cases, intervention was kept to minimum and mainly involved correcting lamb presentation before the ewe continued the birth process.

Data recording. As lambing approaches, the pregnant ewes were observed continuously in the lambing pen for the exact time of lambing. The observation was started immediately after the lamb born by focal animal observation using video camera. The recording was continuous during the first 2 hours following birth.

Ewe data including, grooming the lamb and rumble as well as distress calls, facilitate sucking and prevent sucking (backing, circling, forward movement).

\section{Lamb data.}

A- behaviour patterns, they included. First shake of head, first attempt to stand, first successful stand, time to reach the udder, time to first successful suck and time spent sucking $/ 2 \mathrm{~h}$.

B- lamb performance. Each lamb was weighted $2 \mathrm{~h}$ after of birth by digital weighing machine and lamb weighting was repeatedly each week, until weaning (2 months).

C- lamb mortality. Lamb mortality was recorded during the period from birth until weaning.

Statistical analysis. Tests of significancy (T-test and Chi-square) were used to test the effect of birth difficulty (assisted vs. unassisted) on maternal and lamb behaviours and their consequences on lamb survival.

\section{Results and Discussion}

Assisted ewes did not spend as much time licking $(30.83 \pm 1.39 \mathrm{~min} / 2 \mathrm{~h}, \mathrm{P}<0.05)$ and nosing $(24.25 \pm 1.79$ time $/ 2 \mathrm{~h}, \mathrm{P}<0.05)$ their lambs when compared with unassisted mothers, which tended to express appropriate maternal behaviour at birth (38.52 $\pm 2.96 \mathrm{~min}, 28.80 \pm 1.68$ time $/ 2 \mathrm{~h}$ ) respectively.

With regard to the ewe response to lamb sucking attempts (Table, 1), the rate of ewe standing was found to be higher in unassisted ewes $(25.00 \pm 1.34$ time $/ 2 \mathrm{~h}, \mathrm{P}<0.05)$ than assisted one (20.25 \pm 1.10 time $/ 2 \mathrm{~h})$. This appeared to be due to the higher sucking frequency of lambs from unassisted mothers which appeared more active at birth associated with better mothering ability. On the other hand, assisted ewes were found to be more aggressive towards its neonate by moving away when the lamb attempts to suck $(9.80 \pm 0.37,12.90 \pm 0.84$ and $10.50 \pm 0.50 \mathrm{time} / 2 \mathrm{hr}$ ) than unassisted one $(8.00 \pm 0.40,10.20 \pm 0.52$ and $7.66 \pm 0.88$ time/2 h) respectively.

With reference to lambing vocalization (Table, 1), the data demonstrated a significant differences $(\mathrm{P}<0.05)$. Rumble call is a specific lambing vocalization associated with maternal care that plays an important role in ewe-lamb bond formation (Nowak, 1996), it was found to be significantly higher $(\mathrm{P}<0.05)$ in unassisted mothers $(298.50 \pm 14.15$ time $/ 2 \mathrm{~h})$ that is characterized by adequate mothering ability than assisted one $(235.60 \pm 20.10$ time/ $2 \mathrm{~h})$. While for distress call which usually associated with aggression and the separation from the neonates there was the opposite. These results were in agreement with studies reported by (Alexander et al., 1990; Dwyer et al., 2001 and Dwyer, 2003) who demonstrated that ewe maternal behaviour was found to be affected by difficult delivery.

The data presented in Table (2) demonstrated that, lamb neonatal progress is a function of proximate mechanisms such as the ease of delivery. These results illustrated that lambs required manual delivery were significantly slower than other lambs to perform all neonatal behaviours. Significantly $(\mathrm{P}<0.05)$, smaller numbers of these lambs were seen sucking within the initial recording period (Table 2). 
Table (1): The effect of birth difficulty on ewe maternal behaviour.

\begin{tabular}{|c|c|c|c|c|c|c|c|c|}
\hline \multirow{2}{*}{$\begin{array}{l}\text { Variable } \\
\text { Treatment }\end{array}$} & \multirow{2}{*}{$\begin{array}{l}\text { Grooming } \\
\text { time } \\
\text { (min) }\end{array}$} & \multirow[b]{2}{*}{$\begin{array}{l}\text { Nosing } \\
\text { frequency }\end{array}$} & \multirow{2}{*}{$\begin{array}{c}\text { Rumble } \\
\text { call } \\
\text { frequency }\end{array}$} & \multirow{2}{*}{$\begin{array}{l}\text { Distress } \\
\text { call } \\
\text { frequency }\end{array}$} & \multirow{2}{*}{$\begin{array}{l}\text { Facilitate } \\
\text { sucking } \\
\text { frequency }\end{array}$} & \multicolumn{3}{|c|}{ Prevent sucking frequency } \\
\hline & & & & & & $\begin{array}{c}\text { Backing } \\
\text { movement }\end{array}$ & $\begin{array}{l}\text { Circling } \\
\text { movement }\end{array}$ & $\begin{array}{l}\text { Forward } \\
\text { movement }\end{array}$ \\
\hline $\begin{array}{c}\text { Assisted } \\
\text { group }\end{array}$ & $\begin{array}{c}30.83 \\
\pm 1.39^{\mathrm{b}}\end{array}$ & $\begin{array}{l}24.25 \\
\pm 1.79^{b}\end{array}$ & $\begin{array}{c}235.6 \\
\pm 20.10^{\mathrm{b}}\end{array}$ & $\begin{array}{r}65.40 \\
\pm 2.54^{\mathrm{a}}\end{array}$ & $\begin{array}{c}20.25 \\
\pm 1.10^{\mathrm{b}}\end{array}$ & $\begin{array}{c}9.80 \\
\pm 0.37^{\mathrm{A}}\end{array}$ & $\begin{array}{c}12.90 \\
\pm 0.84^{\mathrm{a}}\end{array}$ & $\begin{array}{c}10.50 \\
\pm 0.50^{\mathrm{A}}\end{array}$ \\
\hline $\begin{array}{l}\text { Unassisted } \\
\text { group }\end{array}$ & $\begin{array}{c}38.52 \\
\pm 2.96^{\mathrm{a}}\end{array}$ & $\begin{array}{r}28.80 \\
\pm 1.68^{\mathrm{a}}\end{array}$ & $\begin{array}{c}296.5 \\
\pm 14.15^{\mathrm{a}}\end{array}$ & $\begin{array}{l}55.25 \\
\pm 2.05^{\mathrm{b}}\end{array}$ & $\begin{array}{r}25.00 \\
\pm 1.34^{\mathrm{a}}\end{array}$ & $\begin{array}{c}8.00 \\
\pm 0.40^{\mathrm{B}}\end{array}$ & $\begin{array}{c}10.20 \\
\pm 0.52^{\mathrm{b}}\end{array}$ & $\begin{array}{c}7.66 \\
\pm 0.88^{\mathrm{B}}\end{array}$ \\
\hline
\end{tabular}

Capital letters means within the same column carrying different letters are significantly different at $(\mathrm{P}<0.01)$.

Small letters means within the same column carrying different letters are significantly different at $(\mathrm{P}<0.05)$.

Table (2): The effect of birth difficulty on lamb behaviour.

\begin{tabular}{ccccccc}
\hline Variable & $\begin{array}{c}\text { First shake } \\
\text { of head after } \\
\text { birth (min) }\end{array}$ & $\begin{array}{c}\text { First attempt } \\
\text { to stand after } \\
\text { birth (min) }\end{array}$ & $\begin{array}{c}\text { First } \\
\text { successful } \\
\text { stand after } \\
\text { birth (min) }\end{array}$ & $\begin{array}{c}\text { Time (min) to } \\
\text { reach the } \\
\text { udder }\end{array}$ & $\begin{array}{c}\text { First } \\
\text { successful } \\
\text { sucking after } \\
\text { birth (min) }\end{array}$ & $\begin{array}{c}\text { Time (min) } \\
\text { spent } \\
\text { sucking/ } \\
\text { 2hr }\end{array}$ \\
\hline Assisted & 0.43 & 3.66 & 19.07 & 29.65 & 38.47 & 10.78 \\
group & $\pm 0.02^{\mathrm{A}}$ & $\pm 0.21^{\mathrm{a}}$ & $\pm 0.52^{\mathrm{a}}$ & $\pm 0.66^{\mathrm{a}}$ & $\pm 1.28^{\mathrm{a}}$ & $\pm 0.60^{\mathrm{b}}$ \\
Unassisted & 0.36 & 2.92 & 17.18 & 25.44 & 34.67 & 14.38 \\
group & $\pm 0.01^{\mathrm{B}}$ & $\pm 0.17^{\mathrm{b}}$ & $\pm 0.53^{\mathrm{b}}$ & $\pm 0.53^{\mathrm{b}}$ & $\pm 0.75^{\mathrm{b}}$ & $\pm 1.25^{\mathrm{a}}$ \\
\hline
\end{tabular}

Capital letters means within the same column carrying different letters are significantly different at $(\mathrm{P}<0.01)$.

Small letters means within the same column carrying different letters are significantly different at $(\mathrm{P}<0.05)$.

Table (3): The effect of birth difficulty on lamb body weight (kg).

\begin{tabular}{lcccccccc}
\hline Variable & & & & & & & \\
Treatment & Week 1 & Week 2 & Week 3 & Week 4 & Week 5 & Week 6 & Week 7 & Week 8 \\
\hline \multirow{2}{*}{ Assisted group } & 3.45 & 4.43 & 5.35 & 6.48 & 7.40 & 8.38 & 9.40 & 10.08 \\
& $\pm 0.30^{\mathrm{b}}$ & $\pm 0.26^{\mathrm{b}}$ & $\pm 0.34^{\mathrm{b}}$ & $\pm 0.15^{\mathrm{B}}$ & $\pm 0.17^{\mathrm{B}}$ & $\pm 0.23^{\mathrm{B}}$ & $\pm 0.24^{\mathrm{b}}$ & $\pm 0.22^{\mathrm{b}}$ \\
Unassisted group & 4.76 & 5.89 & 7.08 & 8.48 & 9.59 & 10.61 & 11.57 & 12.47 \\
& $\pm 0.12^{\mathrm{a}}$ & $\pm 0.14^{\mathrm{a}}$ & $\pm 0.11^{\mathrm{a}}$ & $\pm 0.15^{\mathrm{A}}$ & $\pm 0.07^{\mathrm{A}}$ & $\pm 0.17^{\mathrm{A}}$ & $\pm 0.05^{\mathrm{a}}$ & $\pm 0.12^{\mathrm{a}}$ \\
\hline
\end{tabular}

Capital letters means within the same column carrying different letters are significantly different at $(\mathrm{P}<0.01)$.

Small letters means within the same column carrying different letters are significantly different at $(\mathrm{P}<0.05)$.

Table (4): The effect of birth difficulty on lamb weight gain (kg).

\begin{tabular}{ccccccccc}
\hline Variable & Gain & Gain & Gain & Gain & Gain & Gain & Gain & Total \\
Treatment & $\mathbf{1}$ & $\mathbf{2}$ & $\mathbf{3}$ & $\mathbf{4}$ & $\mathbf{5}$ & $\mathbf{6}$ & $\mathbf{7}$ & Gain \\
\hline \multirow{2}{*}{ Assisted group } & 0.98 & 0.93 & 1.13 & 0.93 & 0.98 & 1.03 & 0.68 & 6.63 \\
& $\pm 0.12^{\mathrm{b}}$ & $\pm 0.11^{\mathrm{b}}$ & $\pm 0.34^{\mathrm{b}}$ & $\pm 0.05^{\mathrm{b}}$ & \pm 0.15 & \pm 0.13 & $\pm 0.13^{\mathrm{b}}$ & $\pm 0.29^{\mathrm{b}}$ \\
Unassisted group & 1.13 & 1.19 & 1.40 & 1.11 & 1.02 & 0.96 & 0.90 & 7.71 \\
& $\pm 0.19^{\mathrm{a}}$ & $\pm 0.20^{\mathrm{a}}$ & $\pm 0.15^{\mathrm{a}}$ & $\pm 0.12^{\mathrm{a}}$ & \pm 0.15 & \pm 0.14 & $\pm 0.09^{\mathrm{a}}$ & $\pm 0.21^{\mathrm{a}}$ \\
\hline
\end{tabular}

Small letters means within the same column carrying different letters are significantly different at $(\mathrm{P}<0.05)$.

Table (5): The effect of birth difficulty on lamb mortality.

\begin{tabular}{cccc}
\hline Variable & Number & Mortality (\%) & Chi-square \\
\hline Assisted group & $2 / 7$ & $28.57^{\mathrm{a}}$ & $5.38^{*}$ \\
Unassisted group & $4 / 35$ & $11.42^{\mathrm{b}}$ & \\
\hline
\end{tabular}

Different small letters means within the same column are significantly different at $(\mathrm{P}<0.05)$. 
Injury to the foetal CNS, either by haemorrhage or asphaxia, has been shown to be associated with birth stress and prolonged deliveries (Haughey, 1993). Damage to the foetal CNS can cause impaired sucking and locomotor activity in lambs and impairs the thermoregulation in the neonate (Cloete, 1993). The ability to maintain body temperature is related to behaviours (Slee and Springbett, 1986 and Dwyer, 2003), damage to the CNS affecting both behaviour and thermoregulatory ability, may account for the observed slow behaviour of the lambs in the present study following difficult delivery. Moreover, birth difficulty may results in trauma, either physical injury or hypoxia which continue to affect lamb development over the post natal period as mentioned in the previous studies of (Hinch et al., 1986; Cloete, 1993 and Dwyer, 2003) who stated that lambs that had difficult delivery were significantly slower to perform all behavioural landmarks after birth than lambs with uncomplicated delivery.

There was a significant difference $(\mathrm{P}<0.05)$ between the lambs in performance due to birth difficulty (Tables 3 and 4). Lambs born to unassisted mothers had higher growth rate from birth till weaning than lambs from assisted ewes.

The enhanced growth and survival of lambs that were active at birth in this study might be related to the nutritional and immunological benefits of early colostrum ingestion and also to the effects of sucking behaviour on the establishment of ewe recognition in the lamb. The present results were in close accordance with the results of (Nowak et al., 2000 and Darwish, 2004) who demonstrated that lamb growth was greater in lambs that stand and suck quickly in the early post natal period.

Lambs born to assisted ewes had significantly $(\mathrm{P}<0.05)$ Table $(5)$ higher mortality $(28.57 \%)$ than lambs born to unassisted one $(11.42 \%)$. The higher mortality in lambs from assisted ewes might be related to its poor mothering ability associated with frequent separation from their lambs at birth. In addition, lambs born to assisted mothers were less active at birth and take longer time to stand and suck. Consequently higher lamb mortality was recorded where lamb survival is crucially dependent on the expression of adequate behaviours from both the ewe and lamb at birth. Any impairment in these behaviours will increase the probability that the lamb will not survive. Similar results were recorded by (Knight et al., 1988; Alexander et al., 1990;
Fogarity et al., 2000 and Darwish, 2004) who suggested that the behavioural traits, which should theoretically maximize the survival of the lamb including: birth of short or average duration, intense persistent grooming and absence of aggression towards the neonate.

In conclusion, this study had demonstrated that birth difficulty is a risk factor, which had adverse effect on ewe and lamb behavioural progress and consequently affecting lamb survival. Thus lamb behavioural development may be a key factor in promoting lamb survival. Understanding the prenatal processes that affect lamb behaviour is likely to be important in managing sheep flocks for maximum survival of lambs.

\section{References}

Alexander, G.; Steven, S. D.; Bradley, B. and Barwick, S. A. (1990): Maternal behaviour in Border Leicester, Glenvale and Merino sheep. Aust. J. Exp. Agric., 30: 27-38. Clarke, L.; Yakubu, D. P.; Symonds, M. E. (1997): Influence of maternal body weight on size, conformation and survival of newborn lambs. Reprod. Fertil. Dev., 9: 509-514.

Cloete, S. W. P. (1993): Observations on neonatal progress of Dormer and South African Mutton Merino lambs. S. Afr. J. Anim. Sci., 23: 38-42.

Darwish, R. A. (2004): Lamb raising with special reference to performance and mortality. Ph. D. V. Sci. Thesis, Cairo Univ., Egypt.

Dwyer, C. M. (2003): Behavioural development in the neonate lamb: effect of maternal and birth related factors. Theriogeno., 59: 1027-1050.

Dwyer, C. M.; Lawernce, A. B., and Bishop, S. C. (2001): The effects of selection for lean tissue content on maternal and neonatal lamb behaviours in Scottish Blackface sheep. Anim. Sci., 72: 555-571.

Fogarty, N. M.; Hopkins, D. L. and Van de Ven, R. (2000): Lamb production from diverse genotypes. 1. Lamb growth and survival and ewe performance. Anim. Sci., 70: 135-145.

Gama, L. T.; Dickerson, G. E.; Young, L. D. and Leymaster, K. A. (1991): Effects of breed, heterosis, age of dam, litter size and birth weight on lamb mortality. J. Anim. Sci., 69: 2727-2743.

Haughey, K. G. (1993): Perinatal lamb mortality- its investigation, causes and control. Ir. Vet. J., 46: 9-28.

Hinch, G. N.; Davis, G. H.; Crosbie, S. F.; Kelly, R. W. and Trotter, R. W. (1986): Causes of lamb mortality in two highly prolific Booroola crossbred flocks and a Romeny flock. Anim. Reprod. Sci., 12: 47: 61.

Knight, T. W.; Lynch, P. R.; Hall, D. R. H. and Hockey, H. U. P. (1988): Identification of factors contributing to the improved lamb survival in Marshall Romney sheep. N. Z. J. Agric. Res., 31: 259-271.

Morris, C. A.; Hickey, S. M.; and Clarke, J. N. (2000): Genetic and environmental factors affecting lamb survival at birth and through to weaning. N. Z. J. Agric. Res., 43: 515-524.

Nash, M. L.; Hangerford, L. L.; Nash, T. G. and Zinn, G. M. (1996): Risk factors for prenatal and postnatal mortality in lambs. Vet. Rec., 139: 64-67. 
Nowak, R. (1996): Neonatal survival: contribution from behaviour studies in sheep. Appl. Anim. Behav. Sci., 49: 61-72.

Nowak, R.; Porter, R. H.; Levy, F.; Orgeur, P.; and Schaal, B. (2000): Role of mother-young interactions in the survival of offspring in domestic mammals. Rev. Reprod., 5: 153-163.

Rook, J. S.; Scholman, G.; Wing-Proctor, S. and Shea,
M. (1990): Diagnosis and control of neonatal losses in sheep. Vet. Clin. North. An. Food Anim. Pract., 3: 531562.

Slee, J. and Springbett, A. (1986): Early post-natal behaviour in lambs of ten breeds. Appl. Anim. Behav. Sci., 15: 229-240.

Thomas, J. O. (1990): Survey of the causes of dystocia in sheep. Vet. Rec., 127: 574-575. 